\title{
DOS RELATÓRIOS PROVINCIAIS À POLIFONIA DOS MORADORES DO QUILOMBO DE SANTA TEREZA DO MATUPIRI-ANDIRÁ/AM, NORTE DO BRASIL
}

\author{
FROM PROVINCIAL REPORTS TO THE RESIDENTS POLYPHONY OF THE \\ QUILOMBO REMINISCENT OF SANTA TEREZA DO MATUPIRI-ANDIRÁ/AM, \\ NORTHERN BRAZIL
}

Renan Albuquerque*

Georgio Ítalo Ferreira*

\begin{abstract}
RESUMO: Foi feito levantamento historiográfico sobre a temática da escravidão negra na Amazônia, baseado em relatórios provinciais do século XIX, com direcionamento à reflexão sobre o processo de reconhecimento pela Fundação Palmares, bem como a formalização por parte do governo federal, da titulação das comunidades quilombolas do Andirá, onde o Quilombo do Matupiri figura como distrito município de Barreirinha/Amazonas. Ponderamos a respeito dos plantéis de escravizados no Amazonas e na região de Villa Bella da Imperatriz, onde ao período provincial o Andirá estava sob jurisdição. Enveredou-se, dando ênfase à polifonia, para narrativas de colaboradores, que destacaram seus sentidos de viver, festejar os santos, colheitas e plantios, como atos de resistência frente às negações por parte do estado de seus direitos de cidadania, pois, grosso modo, são tratados como refugiados dentro do próprio território brasileiro. Há tempos que os quilombolas do Matupiri esperam por melhorias dentre as comunidades, sobretudo após seu reconhecimento por decreto. Aguardam a instalação de uma escola com melhor infraestrutura, água tratada, transporte escolar e formação acadêmica promovida pelo município. Mas o que se vê é um completo descaso e abandono. Dado o exposto, concluímos que o Matupiri resiste, sobrevive e luta contra injustiças e demais medidas protelares quanto à titulação das terras locais, o que só dificulta a vida da pessoa quilombola na Amazônia.
\end{abstract}

PALAVRAS-CHAVE: Resistência negra. Povos tradicionais. Amazônia.

ABSTRACT: A historiographical survey was made on the theme of black slavery in the Amazon, based on nineteenth century provincial reports, with a focus on the recognition process by the Palmares Foundation, as well as the formalization by the federal government of the titling of the quilombola Andirá, where the Quilombo Reminiscent of the Matupiri figure as district of Barreirinha/Amazonas. We have pondered the plans of enslaved women in Amazonas and in the region of Villa Bella da Imperatriz, where the Andirá was under jurisdiction. It was emphasized, emphasizing polyphony, to narratives of collaborators, who emphasized their senses of living, celebrating the saints, harvests and plantations, as acts of resistance against the denials on the part of the state of their rights of citizenship, because, roughly, they are treated as refugees within Brazilian territory. Matupiri's quilombolas reminiscents have long hoped for improvements among communities, especially after their recognition by decree. They await the installation of a school with better infrastructure, treated water, school transportation and academic training promoted by the municipality. But what you see is complete neglect and neglect. Given the above, we conclude that Matupiri resists,

\footnotetext{
* Pós-doutor em Antropologia pela Pontifícia Universidade Católica de São Paulo (PUC-SP). Doutorado em Sociedade e Cultura na Amazônia pela Universidade Federal do Amazonas (UFAM). Professor permanente do Programa de Pós-Graduação em Sociedade e Cultura na Amazônia da Universidade Federal do Amazonas (UFAM).

** Doutorando do Programa de Pós-Graduação em Sociedade e Cultura na Amazônia, da Universidade Federal do Amazonas (UFAM).
} 
survives and fights against injustices and other landslide measures regarding the titling of local lands, which only makes life difficult for the quilombola people in the Amazon.

KEYWORDS: Black resistance. Traditional peoples. Amazon.

\section{Matupiri: uma comunidade quilombola amazônica}

O município de Barreirinha é distante 331 quilômetros de Manaus, capital do Amazonas, e se localiza no extremo leste do Estado, na divisa com o Pará. Tem população de aproximadamente 30 mil habitantes e a maior parte da população barreirinhense, 17 mil, está sediada na zona rural. O município, no que tange ao aspecto geopolítico, é composto por 106 comunidades rurais, entre elas cabocla (não indígena), indígenas (Sateré-Mawé) e as cinco comunidades quilombola. Para recorte do estudo, direcionou-se o foco a uma comunidade quilombola que surgiu por ocupação de mais de um século por grupos afrodescendentes.

O mito fundador do Quilombo de Santa Tereza do Matupiri está na chegada do movimento Cabano na Amazônia, especificamente na região do Rio Andirá, cujos membros eram mestiços, negros, índios aldeados e destribalizados que coadunavam com os ideais Cabanos, que visava a melhoria das condições de vida das populações mais pobres dessa área do Brasil Regencial (HALL, 2003, p. 18).

Os mitos fundadores são, por definição, transistóricos: não apenas estão fora da história, mas são fundamentalmente aistóricos. São anacrônicos e tem a estrutura de uma dupla inscrição. Seu poder redentor encontra-se no futuro, que ainda está por vir. Mas funcionam atribuindo o que predizem a sua descrição do que já aconteceu, do que era no princípio. Entretanto, a história, como a flecha do Tempo, e sucessiva, senão linear. A estrutura narrativa dos mitos e cíclica. Mas dentro da história, seu significado é frequentemente transformado.

Essa versão histórica é um fato, e talvez justifique a presença negra nessas terras, ainda no primeiro quartel do século XIX. E, nos dias de hoje, os moradores da Comunidade do Matupiri identificam-se como afrodescendentes, pois se consideram descendentes dos negros que lutaram na Cabanagem. Cerqua (2009, p. 40) comenta sobre esse fato histórico desdobrado na região do Andirá:

Em 1835 rebentou no Pará a revolução dos Cabanos. Manaus, preocupada, a 6 de julho pede à Câmara de Lusea (Maués), de quem na época dependia Vila Bela da Imperatriz, que seja enviado um destacamento no "Posto de Parintins" (a Serra) a fim de obstar a entrada dos anarquistas. Mas estes do Tapajós, pelo Arapiuns e pelas matas, alastraram a revolta na nossa região, onde os caboclos, pretos, índios, que moravam na beira dos rios, aderem numerosos, procurando a melhoria de sua vida política, social e econômica [...] Crispin Leão assume o comando no Andirá, espanta Parintins e ocupa Lusea (Maués).

As cinco comunidades quilombolas possuem 227 famílias e 1.135 moradores. Somente na comunidade de Santa Tereza do Matupiri existem aproximadamente 140 famílias quilombolas e uma população de 250 comunitários. No ano de 2013, essas comunidades quilombolas receberam certificação coletiva da Fundação Palmares. Das comunidades reconhecidas pela Fundação Palmares, optou-se por pesquisar o distrito de Santa Tereza do Matupiri com base em relatos orais dos moradores mais longevos e que possuem reconhecimento e respeito dentre os moradores. A comunidade está localizada na margem esquerda do Rio Andirá, a uma distância de aproximada $23 \mathrm{~km}$ da sede de Barreirinha. 
Para se chegar ao local, o transporte é feito via embarcações (barcos, rabetas, voadeiras) e, dependendo do optado, o tempo de viagem varia. Para quem sai de Barreirinha, do Porto do Pucú, utilizando barco regional, o horário de saída é às $14 \mathrm{~h}$, sendo a duração de viagem de três horas, com o bilhete de passagem no valor de $R \$ 10,00$, o que também pode variar de embarcação a embarcação. O horário de retorno à sede do município é perto das $3 \mathrm{~h}$ da manhã, com o intuito de se chegar ao amanhecer, às $6 \mathrm{~h}$. Para quem opta pela voadeira (embarcação veloz), o tempo de viagem é reduzido para 50 minutos ou $1 \mathrm{~h}$, dependendo da condição do regime das águas (cheia e vazante). No caso do rabeta 5.5HP, o tempo é maior, variando em torno das 3h. No Distrito de Santa Tereza do Matupiri, podemos encontrar uma estrutura modesta, com característica similar às demais formações comunitárias às margens de lagos e rios da Amazônia. Na área central da comunidade, situa-se uma igreja e estão construídas modestas casas de comunitários no entorno.

Após reconhecimento e certificação da Fundação Palmares, a luta diária dos comunitários dá-se por uma melhor infraestrutura para a comunidade, pois, até o presente, falta um posto de saúde que atenda à demanda. A realidade do Matupiri é similar a outros povoados da Amazônia, sendo "uma herança dos vários ciclos que capturam a região, impondo modelos com lógicas internas de exclusão. Sobretudo, a negligência do Estado como de executor de políticas sociais e, em casos extremos, de executor de políticas compensatórias" (OLIVEIRA, 1996, p. 186). Nesse particular, a inexistência de infraestrutura e atenção humanizada a pacientes é uma realidade das comunidades quilombolas de Barreirinha. Sem a seguridade biomédica, moradores quilombolas recorrem bastante, ainda hoje, a conhecimentos de medicina tradicional para curar males. Na maioria das vezes se utilizam de ervas, chás e unguentos. São alternativa para o restabelecimento de enfermos. As políticas de exclusão praticadas no interior de Barreirinha são denunciadas por Ranciaro (2004, p. 88):

\begin{abstract}
Através do relato dos ribeirinhos diante da dinâmica social dos acontecimentos vivenciados no seu dia-a-dia, bem como das estratégias políticas propostas pelo poder público local (Prefeitura de Barreirinha), e da proposição de medidas formuladas pelo Governo do Estado, é possível analisar e identificar quais os mecanismos de poder que, articulados entre si, orientam e consolidam o processo de exclusão social nos referidos povoados rurais.
\end{abstract}

Até a década passada, o Matupiri possuía autossuficiência na produção agrícola e criação de animais, do mesmo modo que os demais distritos da região. Produzia-se cana e maracujá, arrumava-se granja, fazia-se roça de macaxeira, mandioca, arroz e feijão. Hoje, com a presença de fazendeiros e madeireiros no entorno, reduziram-se espaços de cultivo e criações declinaram, inclusive a atividade pesqueira foi proibida por latifundiários, que agiram violentamente, cercando rios com fios condutores de eletricidade. Atualmente, com base em depoimentos de colaboradores do Matupiri, não há incentivo para a agricultura familiar por parte do poder público. Busca-se remediar a ausência, recorrendo a conhecimentos tradicionais, no fomento à produção de café, banana, farinha, cará, macaxeira e batata, além do incentivo a granjas domésticas de galinhas e outros animais de pequeno porte, mas são ações incipientes. Suprem o consumo familiar e da comunidade, e, raramente, quando há excedente, ocorrem vendas para a vizinhança comunitária. A ausência do Estado e de suas ações em Santa Tereza do Matupiri pode ser tomada como um exemplo da atual realidade das comunidades interioranas da Amazônia. Oliveira (1986, p. 184) comenta:

No interior da região, contudo, os processos desencadeados foram se agudizando [...] a falta de dinâmica econômica condenou parte desta população à marginalidade, com a proliferação do subemprego e da miséria familiar. O clima de acumulação primitiva da fronteira, favoreceu o 
desrespeito à regulamentação jurídica do trabalho, acarretando semiescravidão, subconcentração e burla de direitos [...].

Populações quilombolas do Matupiri sustentam que a aquisição dominial de territórios incita a retomada de áreas outrora territorializadas. Mas isso só tenderá a ocorrer após a certificação final das comunidades por parte do Incra, o que de fato e de direito outorgará a posse das terras litigiosas a negros na medida em que houver consolidação dos trâmites do processo legal de reconhecimento da área.

Há festividades no distrito de Santa Tereza do Matupiri. Ocorrem a festa da padroeira Santa Tereza D’Ávila, que empresta seu nome ao Matupiri, entre os dias 5 e 15 de outubro; e também a festa em honra a São Sebastião, santo de devoção ou promessa de algumas famílias do local, que acontece em janeiro. Nessas festividades, notam-se a "dança do gambá" e a dança da "onça te pega", ritmos bailados ao som de tambor rústico, formativos de um conjunto de brincadeiras longevo, de influência da cultura negra na região. Braga (2011, p. 165) destaca que "[...] a dança do gambá toma como referência um instrumento musical confeccionado em tronco de madeira, percutido com as mãos que batem no próprio couro".

Além dessas questões de cunho cultural, no ano de 2014, moradores das cinco comunidades quilombolas receberam capacitação direcionada para a elaboração de um "mapa social" com ilustrações que representavam as maneiras particulares de ver as comunidades. Foram concebidos conceitos a partir de vivências conflitantes e enfrentamentos com grandes empresários, que os levaram a desterritorialização em suas próprias terras. Na memória e na fala de nossa colaboradora, percebe-se o momento em que foram retirados de suas terras:

Olha, a chegada dos fazendeiros na região foi em 1986. De 82 pra lá, eles começaram a chegar. Chegaram assim, enganando, comprando terreno a troco de um gravador, troco de motosserra, com troco de uma saca de rancho. A primeira venda de terra que teve na área de quilombo foi do seu Benedito Villas Boas que vendeu. Quando ele vendeu esse terreno que era do pai dele, aí ele chegou lá com uma documentação. Eu tinha eu acho uma idade uns dez anos de idade, quando ele chegou [canto do galo ao fundo] com essa documentação de terra e pedindo que o pessoal assinasse aquele documento, que terreno do pai dele, que o pai dele tinha comprado esse terreno. E já tinha assinado o seu Manoel, o seu Madaleno, o seu Roseno, o seu Manoel Eugenio, que outro senhor de lá, dona Neves, o seu Cabral... Quando chegou na casa do meu pai, que o meu pai também ele não era analfabeto, ele lia um pouco né [canto do galo ao fundo] - meu pai era uma pessoa muito inteligente (ele lia) - aí ele pediu que ele ia ler o papel. Aí, ele leu. Aí, ele perguntou assim: - "Rapaz, pra você quer esse documento?" Resposta: - "Não, porque esse terreno era do meu pai, aí eu preciso organizar o documento." Aí, meu pai disse pra ele: - "Olha, mas pelo que eu sei, o que é do teu pai é essa ilha aqui. Agora, você pega esse mundão de terra aqui não é do teu pai." O que que ele fez, como os outros já tinham assinado, a assinatura do meu pai pra que ia valer, se ele não fosse assinar. Aí, eu sei, foi...Quando ele... o documento... E foi pra Parintins. Aí, quando ele chegou em Parintins, ai ele pegou e vendeu as terras para o seu Waldemar Queirós. aí começou a entrada dos fazendeiros, em 74 por ai nesse período foi em nesse período que teve a primeira venda de terra dentro das nossas áreas, Aí, depois disso, começou a entrar. Aí, veio, comprou [canto do galo ao fundo]... A primeira pessoa que comprou foi um senhor por nome de "Barbado". Aí, depois dele, ele vendeu pra outro senhor; aí esse outro cara vendeu já pro Mendes. Aí, o pessoal foram entrando, foram entrando, foram entrando... Quando a gente nem imaginou, a gente sem as cabeceiras, não era mais a gente. Quando eles começaram, tudo bem. Hoje em dia, de ano passado pra cá, ano retrasado pra cá, a gente não podia mas entrar pr'as cabeceiras pra tirar cipó, não podia mais sobreviver da tiração do Ambé, nem da pescaria, que eles mandavam tirar 
as malhadeiras de dentro d'agua. (Maria Amélia dos Santos Castro, conhecida "Lourdes", 56 anos, agricultora, ex-presidente da federação, articuladora; pesquisa de campo, setembro de 2016).

Ainda hoje, mesmo com o reconhecimento da Fundação Palmares, fazendeiros permanecem nas terras "compradas" no passado dos pais de Dona Amélia, fato este que tenderá a mudar quando houver a titulação que outrora seria expedida pelo Incra com base na Medida Provisória 728/2016 a ser de responsabilidade do MEC. No atual momento, cinco comunidades quilombolas do Andirá ainda aguardam a titulação das terras que lhes darão poder de usufruir de seus espaços.

\title{
2. Província do Amazonas: uma área de prática escravista
}

Na historiografia da Amazônia, Reis (1965) e Araújo (1956) tentam invisibilizar (ou amenizar a visibilidade) a presença negra na região, baseando-se em dados numéricos e populacionais em decorrência de uma agricultura sem grandes impactos econômicos, excluindo a influência cultural nos espaços ocupados. Abreu (2012, p. 25), salienta que:

\begin{abstract}
Mesmo com as dificuldades de conhecer o cotidiano de grupos no período colonial, seja pela característica das fontes, seja pela construção de um paradigma explicativo onde a Amazônia não é escravista e ainda por cima encontra-se na periferia do sistema, grupos de origens étnicas dos mais diversos matizes estão em constante contato, a propriedade de escravos encontrava-se, como já afirmamos, disseminada na sociedade, fato que não se modificará ao longo do século XIX.
\end{abstract}

Em contrapartida, percebemos estudos acurados sobre a mesma temática no atual contexto, que apresentam outra perspectiva sobre o mesmo temário, outrora alijado a segundo plano. Tais pesquisas apontam importantes ponderações. No Pará, Sales (1976) e Figueiredo (1990) reconstituem e enaltecem a presença negra na região. No Amazonas, Pinheiro (1999) e Sampaio (1997) sugerem o silenciamento imposto pela historiografia tradicional à presença do negro no Amazonas. É dessa forma que balizamos nossos grifos, não levando em consideração plantéis trazidos para a Amazônia. Destarte, a proposta não é ponderar sobre dados estatísticos da população negra, mas sim reconstituir o lastro cultural, quer seja no aspecto cultural, folclórico e nas formações quilombolas. Pinheiro (2004, p. 22) cita: "[...] Anônimos, vagavam por uma cidade que, desejando mostrar-se opulenta e moderna, não os ouvia, nem os queria ver na cena pública, além de não lhes assegurar quaisquer direitos". A população amazonense, no período provincial, era marcada pela miscigenação. E por esse motivo era vista de maneira negativa. O prisma era eurocêntrico. Deusa Costa (1999, p. 29) pondera:

[...] desde o período provincial anseio do poder público era ver o Amazonas povoado por uma população de origem estrangeira. A população indígena nativa e o elemento resultante do processo de miscigenação racial entre os povos das mais variadas nações indígenas, o colonizador português e 0 negro, isto é, mestiço, eram visualizados de forma negativa na tradição de uma herança perversa do colonialismo europeu.

Sendo assim, supomos que o Amazonas, mesmo com menor quantidade de escravos negros que demais províncias do Brasil, foi cenário de lutas, fugas, interação social e formações de comunidades afrodescendentes no centro urbano (Comarca de Manaus) e nas áreas periféricas munícipes até então povoadas (Parintins, Tefé e Maués), onde também se notaram lastros de negritude, não apenas na cor da tez, mas em hábitos culturais, culinários, religiosos, nos cantos e batuques das festas folclóricas de boi e de pássaro. A questão da pessoa negra no Amazonas está fortemente presente em registros de periódicos do século XIX, onde os donos da mão-de-obra que se encontrava em fuga a 
descreviam com riqueza de detalhes (cor, profissão) e até mesmo se o escravo fugido havia levado objetos e apetrechos característicos de seu labor diário. Abreu (2012, p. 25) comenta:

\begin{abstract}
Estes anúncios expressavam as ideias de uma classe (a dos proprietários) sobre os escravos (mercadoria, propriedade, e principalmente trabalhadores). Serviram para que construíssemos hipóteses a respeito do complexo fenômeno da racialização e da mestiçagem no Amazonas, mesmo quando a população de escravos não foi numericamente predominante (mas a propriedade de escravos estava disseminada pela sociedade) e a plantation, não era a base econômica na região.
\end{abstract}

O fator em questão era a perda da "propriedade" ou posse do elemento servil (escravizado) por parte do senhorio, claramente explicitado em anúncios de fugas de escravos, em uma sociedade marcada pela distinção de trabalhadores segundo questões fenotípicas. Em sociedades escravistas do século XIX, conceitos de liberdade e escravidão estavam ligados ao termo propriedade e isso era reafirmado em bases jurídicas (LIMA, 2005). A participação do negro no modus vivendi da Amazônia é fato inconteste.

Fugas de núcleos agrícolas do Pará e de fazendas de gado no Nordeste foram vetores para o aporte de negros na cidade de Manaus. No local, eles vendiam frutas e artefatos de madeira, varejo de tabaco e artigos de latão e cobre. Ofereciam serviços de sapateiro, carpinteiros ou ourives (SAMPAIO, 2014). O negro cativo no Amazonas não representou grande plantel, pois para se ter um escravo era necessário ter capital. Não obstante à compra, havia a manutenção da pessoa. O negro foi tratado como artigo de luxo e representação de status para senhores abonados (CAVALCANTE, 2013).

Mas o fato de possuir números irrisórios se comparados às outras províncias não exime a Província do Amazonas de práticas escravistas, fato este que não pode passar despercebido, pois não foram pontuais ou rarefeitas as localidades em que essa mão de obra foi empregada. Houve uma espécie de estratégia pensada para atender a necessidades de senhores detentores de posses bem mais vultosas, e com uma economia relevante, em que se fazia necessária a presença do negro como força motriz.

De acordo com o relatório apresentado à Assembleia Provincial do Amazonas em 8 de junho de 1856, a população escrava negra estava assim disposta na região: Municípios da Capital (Cidade da Barra do Rio Negro, Freguesia de Tauapessasú, Freguesia de Airão); Municípios de Barcellos (Villa de Barcelos, Freguesia de Carvoeiro, Freguesia de Moura, Freguesia de Thomar, Freguesia de São Gabriel); Municípios de Silves (Villa de Silves, Freguesia de Serpa); Municípios de Villa Bela (Villa Bela da Imperatriz, Freguesia do Andirá); Municípios de Maués (Freguesia de Canumã, Freguesia de Borba); Municípios de Tefé (Cidade de Tefé, Freguesia de Nogueira, Freguesia d'Alvellos, Freguesia de Alvarães, Freguesia de Amaturá, Freguesia de Tabatinga). Recompondo o cenário da população, identifica-se que, no ano de 1856, a Província do Amazonas possuía aproximadamente 41.819 habitantes, e, dentre esses, 976 escravos, sendo 475 homens e 431 mulheres. Pereira Costa (2016, p. 54), com base em Relatório Provincial, detalha os números.

Tabela 1 - População Escravizada por Município 1856

\begin{tabular}{|l|c|c|c|c|c|}
\hline \multicolumn{1}{|c|}{ Município } & \multicolumn{2}{c|}{ Adultos } & \multicolumn{2}{c|}{ Menores } & Total \\
\hline & Homens & Mulheres & Homens & Mulheres & \\
\hline Capital & 76 & 102 & 112 & 87 & $\mathbf{3 7 7}$ \\
\hline Barcellos & 14 & 13 & 11 & 7 & $\mathbf{4 5}$ \\
\hline Silves & 50 & 51 & 26 & 18 & $\mathbf{1 4 5}$ \\
\hline Villa Bella & 62 & 37 & 50 & 31 & $\mathbf{1 8 0}$ \\
\hline
\end{tabular}

Fonte: Costa (2016, p. 54). 
No ano de 1859, com base em relatórios da província, percebe-se que o número de escravos da região de Parintins teve acréscimo considerável, talvez devido ao tráfico interprovincial e a nascimentos. Acrescentamos que a tabela elaborada se refere à Villa Bella da Imperatriz e leva em consideração efetivos de escravos constantes na região do Andirá, especificamente em Freguesia do Andirá, hoje pertencente ao município de Barreirinha. Vê-se presença escrava também no município de Maués, que, geograficamente, tem certa proximidade com comunidades que margeiam o Paraná do Ramos e consequentemente com o Rio Andirá, onde hoje estão os quilombos Matupiri, Trindade, Boa Fé, São Pedro e Ituquara.

Tabela 2 - População Escravizada por Município 1859

\begin{tabular}{|l|c|c|c|c|c|}
\hline \multicolumn{1}{|c|}{ Município } & \multicolumn{2}{c|}{ Adultos } & \multicolumn{2}{c|}{ Menores } & Total \\
\hline & Homens & Mulheres & Homens & Mulheres & \\
\hline Capital & 81 & 96 & 110 & 98 & 385 \\
\hline Barcellos & 12 & 10 & 10 & 6 & 38 \\
\hline Silves & 33 & 31 & 18 & 14 & 96 \\
\hline Serpa & 8 & 15 & 7 & 7 & 37 \\
\hline Borba & 45 & 31 & 22 & 18 & $\mathbf{1 1 6}$ \\
\hline Tefé & 27 & 24 & 19 & 21 & 91 \\
\hline Villa Bella & 68 & 37 & 54 & 33 & $\mathbf{1 9 2}$ \\
\hline Maués & 18 & 29 & 9 & 15 & 71 \\
\hline
\end{tabular}

Fonte: Costa (2016, p. 54).

Por volta de 1872, há nova recontagem do plantel escravo no Amazonas e percebese novo crescimento. O total chega a 1.295 indivíduos, mas não são dados confiáveis, o que pode ser identificado em comparações numéricas feitas com mais acurácia. No relatório do Presidente da Província do Amazonas, José Lustosa da Cunha Paranaguá, de 1883, a mão de obra negra servil estava distribuída tanto na capital como na província: Manaus, Manicoré, Itacoatiara, Maués, Borba, Silves, Parintins e Barcelos.

Inicialmente, de 1848 a 1888 foram encontradas referências à presença negra em 36 documentos. Sendo 7 Exposições, 11 Fallas e 18 Relatórios. Constam nesses documentos vários termos para designar o escravo, eles são: elemento servil, escravos e africanos. Podemos observar que não se faz referências ao termo negro, pois constava na província havia negros que não eram escravos, estes eram designados como "africanos livres". Durante todo esse período essas eram as designações que constam nos documentos oficiais. Somente após a abolição legal da escravidão no Estado do Amazonas, em 1884, o negro aparece dissolvido, designado também como trabalhador (...) Não constam nesses documentos séries estatísticas sobre a entrada ou quantidade comprada e saída de escravos, quando muito o valor do imposto sob sua venda. Apesar de noticiar a existência do tráfico de escravos, não se tem uma estimativa. São também imprecisas as estimativas da quantidade de escravos existentes na Província. Mas, é possível entrever pistas de que havia proprietários de terras que dependiam da força de trabalho escravo. (FARIAS JÚNIOR, 2007, p. 6).

As dificuldades em apresentar dados assertivos sobre o ano de 1883 são por conta de coletas informacionais inexatas e incompletas por parte dos presidentes de província da época. Mas, grosso modo, verifica-se população aproximada a 1.120 negros escravos, 
embora se deva ressaltar que o censo se relaciona ao ano de 1881 , divulgado ou usado como contingência atualizada. Daí justifica-se ausência ou confusão em dados do período.

Voltando à questão das subjetividades implicadas à escravidão, cabe afirmar que o comércio de pessoas negras, escravizadas, na província do Amazonas, especialmente em Manaus, era um símbolo de status. Mesmo havendo senhores de grandes posses ou senhores de posses mediadas, aqueles que eram "donos de escravos" eram minoria até mesmo na década de 1850. No entanto, mesmo o Amazonas não tendo uma vocação agroexportadora, o número de escravos paulatinamente aumentou após esse marco histórico, fundamentado sob a égide da Lei Eusébio de Queiroz, de 1850, que decretava o fim do tráfico atlântico - mas não impedia a compra de indivíduos obrigados à servidão via comércio interprovincial, cuja força de trabalho era utilizada em diversas funções na capital e em cidades do interior do Amazonas.

No segundo quartel do século XIX, em Manaus, vivendo período de efervescência econômica e urbanização, com migrações para a cidade sendo a tônica da época, identificase que, com o processo da libertação de escravos sendo efetivado no Amazonas, afrodescendentes buscaram proteção para si e familiares em áreas de mocambos ou quilombos. Procuraram ainda, doutra maneira, firmar-se por meio de compadrios ou afinidades com seus próprios senhores de outrora. A partir disso, projetou-se parcial rede de conformidade. Mas caso essa última possibilidade não se efetivasse, restava fugir e estabelecer laços afetivos, grupos de solidariedade e interação com outros libertos, recriando territórios e espaços de convivência. Os espaços localizavam-se nas proximidades da capital amazonense, em municípios do entorno e às margens do rio Amazonas, o que influenciou no aspecto geopolítico do Estado.

Áreas territoriais ocupadas por negros ganhavam adjetivo que contemplava a origem étnica dos residentes, onde formavam mocambos e redes de afeto. Esses lugares os mantinham livres de seus senhores. Na região de Villa Bella da Imperatriz (antiga denominação da cidade de Parintins), no século XIX, de acordo com o ofício da chefia de polícia da comarca, identificou-se um local onde alguns negros fugidos se amocambavam. Não se sabe onde necessariamente seria esse local, mas atualmente é perceptível a identificação de algumas comunidades rurais cujos topônimos fazem menção à presença negra na jurisdição: Mocambo do Arari, Terra Preta do Andirá, Ilha de Santo Antônio dos Cativos. Cavalcante $(2013$, p. 86$)$ relata, com base em documentos da província:

\begin{abstract}
Em outras áreas urbanas da província, também se pode verificar a configuração dessas paisagens sociais complexas criadas pelas práticas dos fugitivos, reinventadas no cotidiano, servindo para proteção de desertores e fugitivos. Em Vila Bela da Imperatriz o escravo Maximiano José, "mulato, 30 anos, sem barba, alto, oficial de alfaiate" vivia fugido há mais de dez meses no "Quarteirão do Mocambo", distrito desta Vila, para onde várias diligências haviam sido enviadas a fim de capturá-lo. Esses lugares constituíam o típico "campo negro": lugar de conflitos, solidariedades e proteção que marcavam o cotidiano [...] Rotas de fugas, ajuntamentos e mocambos suburbanos revelam as agências e lógicas culturais de africanos e descendentes na construção de espaços de socialização entre fugitivos, desertores, amocambados, libertos, índios.
\end{abstract}

Não sem dificuldades, negros, apesar de circularem livres, ainda eram subentendidos como escravos pela legislação da época. Eram pessoas coisificadas, a melhor dizer. $\mathrm{E}$ isso atesta que o escravismo praticado no Amazonas obedeceu a ritos indicados por diretrizes imperiais. Indivíduos libertos na Província do Amazonas ainda corriam o risco de serem comercializadas por meio do tráfico interprovincial, o que não era incomum ao período. Na prática, esses indivíduos poderiam ser reescravizados e essa era mais uma entre as necessidades para as fugas naquele momento. Isso configurava-se em uma não tão desinteressada libertação para os escravos no Amazonas, que tinha intenções abolicionistas e emancipacionistas. Em um contexto mais acurado, verifica-se que o processo de libertação de escravos no Brasil Imperial estava pautado em ações graduais de 
liberdade, talvez com questões intrínsecas e protecionistas de fundo, ou ainda tentando apenas manter um certo equilíbrio na questão econômica e social do Estado. Era um cenário que facultava a senhores de escravos indenizações por parte do Império, por coadunarem com o processo de libertação de seus cativos.

No ano de 1879, nos plantéis de escravizados de Villa Bella da Imperatriz, a região do Andirá figurava nos quantitativos, como é demonstrado no relatório provincial de 1879 , adequado em uma tabela específica para melhor entendimento.

\section{Tabela 3 - População Escravizada por Município 1879}

\begin{tabular}{|l|c|c|}
\hline \multicolumn{1}{|c|}{ Localidade } & Homens & Mulheres \\
\hline Villa Bella & 50 & 36 \\
\hline Andirá & 1 & 1 \\
\hline Conceição & 23 & 36 \\
\hline \multicolumn{2}{|c|}{ Total } & \multicolumn{2}{|c|}{$\mathbf{1 4 9}$} \\
\hline
\end{tabular}

Fonte: Relatório Provincial de Escravizados em Vila Bella da Imperatriz em 1879.

Nota: Tabela Organizada por Georgio Ítalo.

No ano de 1883, o deputado Joaquim Rocha dos Santos submeteu à Assembleia Provincial Projeto de Lei que propunha indicativas de se promover a entrega de cartas de alforrias para pessoas cativas negras na comemoração do 5 de setembro, data magna da Província do Amazonas. No ano seguinte, o majoritário do Amazonas, Theodoreto Carlos de Faria Souto, teve o mesmo propósito de alforriar escravos antes da data comemorativa do aniversário da Província, fato este que se consumou, independente dos percalços e entraves políticos encontrados, fazendo do Amazonas a segunda unidade provincial do Império brasileiro a abolir a escravidão, em 10 de julho de 1884. O Amazonas, portanto, esteve na vanguarda abolicionista brasileira, dado ter libertado todos os seus cativos quatro anos antes que a histórica Lei Áurea, de 13 de maio de 1888.

\section{Matupiri: resistência e tradição quilombola}

No Quilombo do Matupiri, conforme descrito acima, notamos uma comunidade amazônica com suas idiossincrasias, dispostas na medida em que a ancestralidade negra passou a dialogar com populações locais do Rio Andirá, assimilando muitos hábitos. Das muitas maneiras de resistir a um processo de conquista, quer seja territorial, simbólico e do imaginário, entende-se que manter práticas e costumes pautados em festividades, religiosidades ou espiritualidades tende a ser ato latente de enfrentamento, enfraquecendo a ideia de que teriam sido conquistados, fragmentando-a e mantendo boa resiliência contra o que quer que sobrasse dela. A ação de assimilação era não apenas aparente, mas tinha por meta preservar a essência das pessoas negras. Bruit (1995, p. 168) aponta que:

A simulação foi percebida por certas autoridades, mas aqui aparentemente assinalada como alguma coisa insólita que impedia simplesmente entender os atos dos índios. Um corregedor do Peru informou em 1585 que os índios "usavam suas danças e festas e folias, comendo e bebendo juntos, para ficar bêbados; mas as noutras coisas que fazem não se entendem. É curioso a observação da autoridade que acredita entender as danças, as festas e a bebedeira, e não enumera as "outras coisas" que não se entendem. Que coisas seriam essas? Provavelmente alguns gestos, rituais cotidianos, sinais sobre certos lugares onde escondiam os ídolos e que conheciam, reverências a esses lugares ou a lembranças que a dança e a bebedeira resgatavam [...] Para Las Casas, a simulação escondia o rancor pela destruição e o genocídio; para outros cronistas encobria o desejo e a 
intenção de preservar os traços culturais mais queridos, como a religião. Em ambos os casos trata-se de um mecanismo de defesa, de sobrevivência, de deculturação, de resistência, que não foi visualizado nem entendido pelas autoridades nem pela maioria dos espanhóis, que passaram a ser ludibriados politicamente.

Das muitas festividades existentes no Quilombo do Matupiri, que, como descrevemos, tinham por meta a aceitação no seio social como um todo, destacam-se as festas de santos, de boi-bumbá, do gambá, a feira cultural quilombola e as pastorinhas. Eram inicialmente eventos pequenos, mas que representam sentidos múltiplos adornados pelos festejos da comunidade e trazem antigas memórias intrínsecas em seus enredos; e, pelo fato de ainda existirem, podem ser entendidos como atos de resistência histórica. Apesar do já comentado isolacionismo em relação às políticas públicas estatais, a comunidade quilombola, imbuída do seu espírito beligerante - algo que se tornou mais explícito após a reconhecimento pela Fundação Palmares - fez com que essas outrora tímidas festas ganhassem uma maior amplitude e aceitação por parte da juventude.

Nós temos todos esses impasses de se preocupar em se resgatar as danças culturais da comunidade quilombola: o Jaçanã, a Onça-te-pega, a Garcinha e o Gambá. Mas o que a gente destaca é a Onça-te-pega, que já está conhecida aí pra fora. O Onça-te-pega, as pessoas cantam e as crianças dançam. Umas se vestem de onça e as outras se vestem de veado, que são animais típicos da nossa região. Aqui, então, as pessoas cantam e as outras se vestem e começam a dançar sem par. Sempre que tem eventos na escola ou na comunidade, a gente solicita essas danças, inclusive a gente está levando lá pra Barreirinha, na educação do campo, a ajuda dos alunos pra fazer essa dança da Onça-te-pega. Então, a gente está resgatando a nossa cultura, que tanta gente nem conhecia e a gente está passando a conhecer, juntamente com os alunos. Só os mais antigos conheciam, e agora não só nós, mas as crianças também estão conhecendo. (Taciara Raquel dos Santos Castro, professora 31 anos, entrevista concedida em 12 de setembro 2016, na Comunidade do Matupiri).

Uma data marcante dentro da Comunidade do Matupiri, hoje, é a feira cultural, realizada em alusão ao Dia da Consciência Negra, em 20 de novembro, quando comunidades quilombolas do Andirá (São Pedro, Ituquara, Trindade e Boa Fé) se reúnem no Matupiri para a realização do evento. Durante a feira, são apresentadas danças (Gambá, Onça Te Pega), artesanatos e comidas típicas que fazem menção à cultura negra. Segundo a professora Tarciara Raquel, hoje os comunitários não têm mais vergonha de dizer que são quilombolas e se sentem orgulhosos por sua origem negra.

É uma parceria da comunidade e as escolas, sendo o festival agora final de outubro, porque em novembro a gente vai ter a feira e a gente trabalha. A feira é uma coisa e o festival é outra. A feira da escola geralmente é separada da feira dos remanescentes quilombolas. Ano passado, nós trabalhamos juntos, foi só um dia e essa vez trabalhamos relacionados à cultura dos povos. Já o festival é uma outra data. A gente senta com os professores, o pessoal que está à frente do boizinho, que é da comunidade, e comunitários [...] A gente trabalha na divulgação da cultura também, os trabalhos, os produtos que eles estão produzindo, eles trazem pra divulgar, pra expor. E esse ano a gente está querendo fazer diferente com eles. Nós sentamos pra apresentar, fazer um desfile, ter um almoço com todas as comunidades. Aí, à noite vai ter as brincadeiras entre as comunidade, que é o futebol que não deixa de ser, que é um esporte bastante praticado aqui, que não sai, que é sempre mais forte que tem, que é o esporte... $E$, à noite, vai ter o desfile da garota quilombola, e a gente quer também ter um baile dançante à noite... Mas, durante a manhã, vai ter a exposição dos produtos das comunidades: cada um vai ter um grupo, fazer sua barraca e expor. 
(Tarciara Raquel dos Santos Castro, professora 31 anos, entrevista concedida em 12 de setembro 2016 na Comunidade do Matupiri).

Percebe-se, no depoimento de nossa colaboradora, a preocupação que a escola da comunidade do Matupiri tem em resgatar antigas brincadeiras presentes na memória das pessoas mais velhas, que sempre fazem menção a esse tempo, época que até o término do trabalho de um puxirum era sinônimo de festa, ocasião em que se tocava o Gambá e dançava o restante do dia. Talvez soasse como uma celebração pelas atividades do roçado (destoca ou plantio), as quais tivessem sido profícuas, sem qualquer anormalidade, onde todos houvessem se empenhado para que a empreitada desse certo. A reconstituição desses momentos é inclusa como atividade didática, de sala de aula, concernente a uma atividade teatral que revive antigos momentos festivos do Matupiri.

De acordo com a professora Tarciara Raquel, trata-se de um projeto chamado "Educação do Campo", por meio do qual se adota a própria realidade como exemplificação didático-pedagógica, pois atende a anseios de comunitários e alunos, não como uma visão de funil, mas se busca a valorização do senso de pertença para o posterior conhecimento da realidade de outros lugares; e isso tem contribuído para que a identidade seja construída gradativamente. $O$ fato de os professores e as professoras serem quilombolas é uma ajuda superlativa no desenvolvimento cultural da comunidade, pois no atual contexto a escola não fica mais sem esses profissionais, um fato este que ocorria muito no passado. Nossa colaboradora relata:

Olha, a gente tem 15 professores e, antigamente, eles chamavam professores de fora pra lecionar aqui. Assim é o termo que eles usavam. Então, vinha de fora os professores. Hoje não, nós temos dentro de nossa comunidade mesmo. São filhos da terra mesmo. São poucos que não são daqui, e já tens uns em formação em inglês, pedagogia, geografia, história, e outros que estão concluindo também. O número de professores aumentou muito, e de alunos também, e hoje nós temos 380 alunos divididos em educação infantil, ensino fundamental e ensino médio. Então, hoje nós temos um grande processo educacional que já avançou. Antigamente, tinha até o nono ano e, antes disso, era até o quarto ano, e tinha que ir daqui pra estudar em Barreirinha, em Parintins. Hoje, eles estão agora aqui na nossa vila. As crianças não precisam mais se deslocar de sua terra natal pra outras cidades e inclusive existe aquele impacto, aquele apoio que não tem lá fora. Alguns desistiam e voltavam pra comunidade e ficavam um tempo sem estudar e, hoje, nós já temos bastante alunos e são poucos os que não têm o segundo grau completo. (Professora Tarciara Raquel dos Santos Castro, 31 anos, entrevista concedida em 12 de setembro 2016 na Comunidade do Matupiri).

Há sinalização e vontade da equipe gestora de se criar uma Proposta Pedagógica que atenda às necessidades e interesses de todos, pois, de acordo com a professora Tarciara Raquel, assim como existe na Secretaria Municipal de Educação (SEMED) uma Coordenação de Educação Escolar Indígena (PNE no 10.172/2001), no município de Barreirinha, a mesma entende que é imperativo que também exista uma Coordenação de Educação Quilombola.

[...] Sim, a gente tem, inclusive, os professores que já pediram para a gente colocar o currículo lá no Setor Pedagógico. Quando tiver Encontro Pedagógico pra gente colocar, pra gente trabalhar na escola, trabalhar na Cultura Quilombola, que não pode deixar jamais que seja esquecida pela nossa comunidade. Já tínhamos conversado e estamos voltando pra conversar novamente, pra ver se a gente pode lutar por um espaço na secretaria de educação de ter o setor quilombola. E já que tem o [setor] dos indígenas, nós queremos ter um espaço nosso lá também. (Professora 
Tarciara Raquel dos Santos Castro, 31 anos, entrevista concedida em 12 de setembro 2016 na Comunidade do Matupiri).

Essa preocupação não é irrisória, pois desta forma as Comunidades Quilombolas do Andirá terão um respaldo formal, conforme preconiza a Lei 10.639, de 9 de janeiro de 2003, que estabelece a obrigatoriedade do Ensino de História e Cultura Afro-Brasileira e Africana. Pelo entendimento dos professores do Matupiri, seria uma Educação Escolar Quilombola, e não somente uma mera adaptação do modelo escolar nacional, que até 2003 excluía a História Africana. Pela LDB (1996, p. 20-41), é notório o disposto:

Art. 1ํ A lei no 9394, de 20 de dezembro de 1996, passa a vigorar acrescida dos seguintes arts. $26-\mathrm{A}, 79-\mathrm{A}$ e 79-B: Art 26-A. Nos estabelecimentos de ensino fundamental e médio, oficiais e particulares, torna-se obrigatório 0 ensino sobre História e Cultura Afro-Brasileira. $\$ 1^{\circ} \mathrm{O}$ conteúdo programático a que se refere o caput deste artigo incluirá o estudo da História da África e dos Africanos, a luta dos negros no Brasil, a cultura negra brasileira e o negro na formação da sociedade nacional, resgatando a contribuição do povo negro nas áreas social, econômica e política pertinentes à História do Brasil.

$\S 2^{\circ}$ Os conteúdos referentes à História e Cultura Afro-Brasileira serão ministrados no âmbito de todo currículo escolar, em especial nas de Educação Artística e de Literatura e História Brasileiras. Art 79-B. O calendário escolar incluirá o dia 20 de novembro como Dia Nacional da Consciência Negra.

Essas reivindicações são sempre fundamentadas a partir de informações acadêmicas, leituras de mundo, autodeclaração e valorização cultural, e, apesar da fala branda, percebe-se na persona da professora Tarciara Raquel uma nova liderança dentro da Comunidade Quilombola de Santa Tereza do Matupiri. Em uma caminhada pela comunidade, ela nos ciceroneou e em uma conversa informal, durante o trajeto para conhecer moradores, nos falou que está pesquisando a história daquele lugar, pois percebe que há muita variabilidade sobre muitos fatos. Por exemplo, um deles é sobre o surgimento do Matupiri. Segundo seu prisma, a publicação de um livro com a perspectiva de uma mulher quilombola, sobre o seu próprio espaço de nascimento e vivência, dará um sentido unívoco e muito mais efetivo a respeito das muitas histórias do Quilombo de Santa Tereza do Matupiri.

\subsection{Festas de santos: promessas originárias de resistências}

Uma das festividades que também atravessa o tempo, e talvez seja tão antiga quanto a própria comunidade, seja a festa de santo. E não há uma apenas. Há variadas. Elas possuem traços do catolicismo bem marcantes na maioria das cidades amazônicas e no Quilombo do Matupiri não é exceção. Grosso modo, não se pode falar sobre o processo de conquista da Amazônia sem mencionar as ordens religiosas que se estabeleceram na região, bem como as formações de missões ao longo dos rios da Amazônia, que em muitos casos originaram as cidades contemporâneas e que, no seu surgimento ou seu ínterim, foram consagradas a algum santo católico, como assinala Maués (1995, p. 72):

As crenças do catolicismo de fontes ibéricas se mesclaram com crenças indígenas e africanas, contribuindo para o desenvolvimento das festas populares de santos (com aspectos profanos nem sempre de agrado das autoridades laicas e religiosas), das práticas de feitiçaria, dos aspectos demoníacos, das orações fortes, das pajelanças e dos calundus.

A conquista espiritual da Amazônia ocorreu devido a todo um trabalho de cristianização das ordens religiosas: mercedários, capuchinhos, franciscanos e jesuítas, 
sendo que estes últimos executaram um trabalhado de grande persuasão entre os povos indígenas da Amazônia, tendo sua história marcada por expulsões e retornos à região. $\mathrm{A}$ presença religiosa, e principalmente a jesuíta, portanto, teve importância capital no que tange à expansão e resguardo das terras conquistadas e catequizadas sob a égide da Coroa. De acordo com Mello (2009, p. 251-252):

Consideramos as Juntas das Missões Ultramarinas como desdobramento importante do projeto de conquista português de "dilatação da Fé e do Império". Funcionavam as Juntas como mecanismo ideal para regular as atividades missionárias, como já salientamos nas atribuições e competências no capítulo antecedente, mas também como agentes mediadores das políticas coloniais [...] Muito embora a estratégia de evangelização dos índios proposta pelas ordens religiosas atuantes na América portuguesa, principalmente os jesuítas, tenha entrado diversas vezes em conflito com os colonos e com o clero secular, não se pode negar que as missões desempenharam um papel importante um papel importante como 'unidades de ocupação' e de defesa do território ultramarino.

O processo de conquista territorial empreendido tanto por Espanha quanto por Portugal sempre se utilizou da mão de obra religiosa, ou seja, de missionários que estavam presentes em quase todas as expedições realizadas por essas duas Coroas. Tanto que muitos dos relatos conhecidos nos dias atuais sobre a colonização da América (Las Casas), ou mais especificamente sobre o Brasil e a Amazônia, foram grafados nos diários de alguns missionários, e nesse caso citamos Acuña e Fritz, dois agentes do messianismo na região. Igualmente, Frei Gaspar de Carvajal esteve na embarcação de Francisco de Orellana. Foram homens, por exemplo, que, apesar das subjetividades em seus relatos, deixaram suas impressões sobre o processo de ocupação territorial e espiritual da Amazônia. Silva (2004, p. 35) dispõe:

Os religiosos acompanharam as expedições espanholas, portuguesas e francesas. Como ação interventiva da conquista e da colonização ibérica são também os organizadores das aldeias, primeiros aglomerados populacionais criados sobre agrupamentos originários. Cada lote definido na competição mercantil era um espaço conquistado para colonização espiritual.

As ordens religiosas, como basicamente também ocorrera no front de batalha por território, eram guiadas no sentido de terem uma relação proximal com os povos originários. $\mathrm{Na}$ ação de aproximação a ameríndios, muitas vezes paladinos da evangelização logravam êxito, mas em diversos momentos a catequização enfrentava resistência por parte dos étnicos, que não aceitavam a fé católica e, como retaliação, reagiam a essas investidas da cristandade, chegando a saquear e queimar capelas e imagens de santos. Pinto (2006, p. 125) enfatiza:

Os seus próprios relatos, entretanto, nos fornecem elementos suficientes para concluirmos que essas relações entre índios e missionários eram fortemente marcadas por manifestações de resistência que iam desde a habitual recusa ao batismo e a participação em atos religiosos e a aceitação dos sacramentos, até a destruição de capelas e igrejas, profanação de objetos sagrados e violência contra a pessoa dos padres que, em muitos casos, culminaram com o assassinato.

Apesar de algumas ações com resultados negativos, ainda assim uma das influências marcantes do catolicismo na Amazônia é a "Mariologia", a devoção dos povos amazônicos à Virgem Maria. O Círio de Nazaré, em Belém do Pará, é uma das maiores expressões "Marianas" das Américas, similares à "Aparecida" no próprio Brasil e 
"Guadalupe" no México. Muitas cidades no rincão da hinterlândia são devotadas à doutrina cristã católica. Neves (2010, p. 14) acentua:

A presença da Virgem Maria na região Norte está ligada diretamente às ordens religiosas no período da colonização. Nesse período, o trabalho de catequizar empreendido, principalmente, por carmelitas, jesuítas e mercedários, teve um papel fundamental não só na formação de quase todos os povoados no Rio Negro como também na solidificação do nome da mãe de Jesus. Para se ter uma ideia da forte influência dessas ordens, os carmelitas chegaram ao Rio Negro em 1695 e, nas cercanias do Forte de São José, levantam a Capela de Nossa Senhora da Conceição, feita de madeira, barro e palha. Feito isso, tomam a Virgem como padroeira do núcleo que, futuramente, constituiria a cidade de Manaus, fundada a partir da fortaleza São José do Rio Negro (...) De Belém a Manaus, da ocupação da Bacia Amazônica à exploração de leste a oeste da Amazônia, a Virgem foi sempre louvada.

Nesse contexto, iniciado no período colonial, e que se espraiou pela Amazônia, situamos as festas de santos católicos, sendo que os mais populares na região do Baixo Amazonas são exatamente as três divindades cultuadas no Quilombo do Matupiri: Santa Tereza D'Ávila, São Sebastião e a Santíssima Trindade. Segundo relatos de moradores entrevistados, as festividades remontam ao surgimento da comunidade, e os próprios quilombolas foram os construtores da Igreja de Sebastião, que fica na primeira "Cabeceira da Campina", no Matupiri, sendo avistada assim que se chega à comunidade por via fluvial.

Ela é desde o começo da comunidade, só que ela mudou, ela começou feita
de palha, depois foi feita de barro, e de barro ela já passou pra estrutura de
cimento. Mas a [canto de galo ao fundo] coluna dela é feita de argila, e eu
ainda carreguei esse tijolo que o meu pai e meus tios faziam, aqueles tijolos
de barro assim, inteiro, né. Eles faziam aquelas caixinhas assim, e quando
ficava seco, aí eles botavam pra gente carregar, pra lá pra fazer a igreja.
Não tinha tijolo. Eles eram feitos de adubo [canto de galo ao fundo]. Foram
feitos pelos próprios moradores lá, que eram meu avô, meu pai, meus tios,
minhas tias, e tudo eles se juntavam e faziam pra aquela igreja de São
Sebastião e de Santíssima Trindade. Eles vieram do princípio, porque eles
adotaram esses dois santos. Depois, veio a Santa Terezinha, que eles
arranjaram e ela ficou. Aí, foi esse tempo que veio os padres, e, antes disso,
só era o São Sebastião e a Santíssima Trindade. Está funcionando, sim, ela
funciona mais no mês de janeiro, mas sempre a gente dá um lembrete,
inclusive quinta-feira teve limpeza na área da frente. Quem atende pela
paróquia [fazendo pergunta a outra pessoa] é esse Pe. Carlos Caridade por
que agora faz um tempo que não recebemos visitas de padre, mas a
relação, graças a Deus, é boa. Por isso eu digo assim: nós temos duas
igrejas, sendo duas católicas e uma adventista, mas tudo cuida do que é
seu, não tem briga não tem desavença por causa de religião, porque, até
por conta de religião, pra mim é uma coisa inútil né, porque é um só Deus,
né. Por que brigar? (Maria Amélia dos Santos Castro, conhecida como
"Lourdes", 56 anos, agricultora, ex-presidente da Federação Quilombola,
articuladora, entrevista concedida em 10 de setembro 2016 na Comunidade
do Matupiri).

De acordo com a fala de Dona Maria Amélia, houve a substituição do padroeiro da Comunidade do Matupiri e isso ocorreu a partir da presença efetiva da Igreja Católica, que secundaria as duas divindades já cultuadas pelos comunitários e instituiria Santa Tereza D'Ávila como nova padroeira. Mas os moradores devotos de São Sebastião, ao que parece, aceitaram tal mudança em parte, pois continuaram a realizar as festividades do santo, que soou como um processo de resistência a essa imposição. Sendo assim, a Festa em honra a São Sebastião passou a ser celebrada em dois momentos distintos: na igreja homônima e 
em um rito de Santo de Promessa, promovido pelos quilombolas. Concomitante aos ritos católicos, moradores do Matupiri também realizam a sua profissão de fé, no festejo a São Sebastião, indo para as matas retirar um tronco de "marupá" ou "molongó" (madeira leve) com aproximadamente 10 metros de comprimento. O tronco é enfeitado com flores, frutos e palhas, sendo erguido por todo o período em que a festa dura. Galvão (1976, p. 52) indica que "[...] um varão de sete a oito metros que se prepara em uma das roças próximo à cidade. No dia nove os devotos o levavam em procissão até a frente da igreja onde era plantado, em meio de música e foguetearia. Promesseiros derramavam água na base do mastro".

Atualmente, com a festa de São Sebastião, o santo passou a ser o padroeiro dos quilombolas, pois a ele se penhorou um pedido espiritual de que, se a comunidade fosse atendida, a festa seria realizada nos moldes de antigamente. De acordo com a colaboradora Dona Amélia, o pedido feito a São Sebastião foi que o processo de reconhecimento e titulação das terras quilombolas ocorresse sem maiores problemas e fosse favorável a moradores dos Quilombos do Andirá. Com o pedido atendido, devotos passam a ter a obrigação de cumprir a promessa, pois de certa forma o que está em jogo é a honra de todos os moradores dos quilombos. As festividades a São Sebastião em Matupiri têm característica de novena, pois, como o próprio nome diz, são nove dias. É uma comemoração que exige determinado tempo de preparo e realização. Os detalhes são relatados por nossa colaboradora.

Olha, as festividade, nós temos as festas religiosas, onde a escola faz parceria com a comunidade, o presidente, e também o presidente de igreja e o presidente administrativo, tem sempre reuniões com os comunitários e as autoridades da comunidade pra decidir quando vai ser a festa e de que forma. Divide-se as esquipes e a escola não deixa de participar desses eventos. Assim também, quando a escola tem seus eventos, a comunidade participa, que é o boizinho da escola, gincana cultural, a gente tem feito também a consciência negra. $E$ também o ponto das festividades é a festa de Santa Terezinha, que é a padroeira da comunidade, que geralmente acontece em outubro, dia 15 de outubro; e a de São Sebastião, que é considerado o padroeiro dos quilombolas, e essa festa de são Sebastião é em janeiro. Então, nós temos três festas, são Sebastião, santíssima Trindade e a de santa Terezinha. São os eventos religiosos. E a gente tem outros eventos que a gente está realizando na comunidade, que são os campeonatos, que é campeonato da comunidade, campeonato da escola, festival da escolinha e a festa quilombola que irá se realizar dia 20 de novembro. (Professora Tarciara Raquel dos Santos Castro, 31 anos, entrevista concedida em 12 de setembro 2016, na Comunidade do Matupiri).

Tradicionalmente, a festa em honra a São Sebastião, conhecido "Santo Guerreiro", ocorre de 12 a 20 de janeiro, e é exatamente por esse período que a igrejinha recebe uma pequena reforma, para receber devotos, pagadores de promessa e demais moradores das comunidades circunvizinhas ao Matupiri. Durante os festejos, acontecem novenas, torneios de futebol, festas dançantes, vendas de comida e leilões. Para a realização, não há ajuda financeira externa, as despesas são de responsabilidade dos moradores da comunidade do Matupiri.

Para o desfecho da festa, existe a derrubada do "Mastro do Santo", ocasião em que moradores se reúnem e tanto crianças quanto adultos tentam pegar algum prêmio, brinde, fruta e em algum momento uma certa quantia em dinheiro. Objetos ou guloseimas ficam pendurados no mastro pelo período de realização da festa. Mas a derrubada não seria o momento final da festa. Tem um momento em que os quilombolas chamam de "Festa do Arranca Toco", visto que o "Mastro do Santo" é derrubado com golpes de machado e somente a parte superior é retirada. A base do mastro permanece enterrada e, no dia seguinte, devotos, moradores e pagadores de promessa se reúnem para desenterrá-lo. Como já se encontram reunidos, aproveitam o ensejo e a estrutura existente da festividade 
em honra ao santo de promessa e realizam comemoração dançante na Comunidade Quilombola do Matupiri. Percebe-se a descrição desses momentos nas falas de nossa colaboradora.

\begin{abstract}
A festa do padroeiro, nós escolhemos um padroeiro pra ser o padroeiro dos quilombolas, é o São Sebastião, dia 20 de janeiro, e a padroeira da comunidade é Santa Terezinha, que começa dia 5 de outubro, e de 5 vai até dia 15, e do São Sebastião vai de 12 a 20 janeiro e no dia 20 ainda tem o "arranca toco". Nós temos mais uma padroeira que a gente festeja, e às vezes festejamos também em junho, que é a santíssima trindade. Isso no Matupiri mesmo. E nós não temos a igreja dela, ela usa a igreja da padroeira. (Maria Amélia dos Santos Castro, conhecida como "Lourdes", 56 anos, agricultora, ex-presidente da Federação Quilombola, articuladora, entrevista concedida em 10 de setembro 2016 na Comunidade do MatupiriAndirá/AM).
\end{abstract}

A festa de São Sebastião foi descrita exatamente por ser um dos mais antigos encontros coletivos animados da Comunidade do Matupiri, e, depois que ganhou status instituído como Santo de Promessa dos Quilombolas, ou, melhor dizendo, o santo da vitória da conquista dos direitos quilombolas, a relação apenas se estreitou. Mesmo quando ocorreu a mudança de padroeiro, a manutenção dos festejos a São Sebastião foi intrinsecamente entendida como verdadeira forma de resistência, pois é ele quem guia quando não se tem mais a quem recorrer. Segundo os quilombolas, São Sebastião intercede por eles, pois se trata de um santo que foi soldado, e, portanto, é indelével e afeito a questões beligerantes, similares à luta por terras que os quilombolas do Rio Andirá vêm travando junto à Justiça ao longo dos tempos.

Ao presente momento, quilombolas do Matupiri ainda aguardam a titulação de suas terras pelo governo federal, o que seria a última ação após o reconhecimento. Desde o governo golpista, de 2016, a União vem postergando essa oficialização. Enquanto isso, moradores do Matupiri resistem bravamente, fazendo de seus dias uma revolução cabana.

\title{
4. Considerações finais
}

De acordo com o exposto, percebe-se uma Amazônia diferente da versada pela historiografia tradicional, que alcunhava a região rarefeita da presença negra, pois apenas levava em consideração plantéis trazidos às Províncias do Norte. Dava-se mais relevância aos dados estatísticos, ignorando a influência de todo um universo cultural que influenciou as populações amazônicas, quer sejam tradicionais não indígenas e quilombolas.

A articulação das populações quilombolas do Amazonas vai de encontro à ideia de que o Amazonas era uma área de baixíssima presença negra. Fato este que foi desconstruído a partir dos anos 2000 , quando oito comunidades quilombolas em diferentes localidades amazonenses foram reconhecidas. Dentre esse reconhecimento da Fundação Palmares, ilustramos as cinco comunidades quilombolas do rio Andirá, ante as quais demos destaque para a Comunidade de Santa Tereza do Matupiri, núcleo populacional que, de acordo com os relatos de moradores mais velhos, foi o local onde se iniciou o quilombo do Matupiri.

A Comunidade Quilombola do Matupiri atravessou o tempo mediante processos de ressemantização, modificando-se de quilombo local para translocal. Além disso, seus integrantes buscaram ainda formação via estudos formais, escolares e universitários, indo a centros urbanos do entorno em busca de conhecimento. Não se tratou de fuga ou alienação. A ação teve como meta identificar saberes e oportunidades para se defender, para lutar por suas terras e seus direitos ideológicos. Em Matupiri, viver e festejar sua liberdade, seus santos, plantios e colheitas são ações entendidas como atos de resistência. 
E são exatamente essas ações, esses atos de resistência, que hoje, no Matupiri, fazem frente ao tratamento com descaso por parte do novo governo federal, mesmo após o reconhecimento pela Fundação Palmares. As titulações de terras que deveriam ter sido entregues após 2013 não chegaram até os quilombolas, em claro ato de deslegitimação da história. Os comunitários não possuem o mínimo de infraestrutura (esgoto, água encanada, coleta de lixo, UBS, transporte escolar), sem mencionar em uma escola que atenda a demandas de alunos das comunidades do entorno.

Ademais, a visão geografista e biologista (ALMEIDA, 2017) coloca a pessoa amazônica aquém dos princípios garantidos pela Constituição do país, que por esta vasta região é quase letra morta. Todavia, mesmo com a marginalização por parte do governo, o espírito revolucionário cabano ainda vive em terras de Santa Tereza D’Ávila do Matupiri.

\section{Referências}

ABREU, Tenner Inauhiny de. 'Nascidos no Grêmio da Sociedade": racialização e mestiçagem entre os trabalhadores na Província do Amazonas (1850-1889). 2012. Manaus: Dissertação (Mestrado em História Social) - Instituto de Ciências Humanas e Letras, Universidade Federal do Amazonas, Manaus, 2012.

ALMEIDA, Alfredo Wagner Berno de. Introdução; Quilombo: terra e problema. In: Jamary dos pretos: terra de mocambeiros (Projeto Vida de Negro). São Luís: SMDDH/CCN- PVN, 1998. Coleção Negro Cosme, vol. 1. p. 13-25.

Antropologia dos arquivos da Amazônia. Rio de Janeiro: Casa 8; Fundação Universidade do Amazonas, 2008.

. Territórios e territorialidades específicas na Amazônia: entre a "proteção" e o "protecionismo". Caderno CRH, Salvador, v. 25, n. 64, p. 63-71, jan./abr. 2012.

Os quilombolas e a base de lançamento de Alcântara: laudo antropológico. Brasília: MMA, 2006.

; RANCIARO, Maria Magela Mafra de Andrade. Mapeamento Social como instrumento de gestão territorial contra o desmatamento e a devastação: processo de capacitação de povos e comunidades tradicionais: quilombolas do rio Andirá: Santa Tereza do Matupiri, São Pedro, Trindade, Boa Fé e Ituquara/Barreirinha, Amazonas. Manaus: UEA, 2014.

AMÉLIA, Maria. Trilhas percorridas por uma militante quilombola: vida, luta e resistência! Rio de Janeiro: Casa 8, 2016.

ARAÙJO, André Vidal. Introdução à sociologia da Amazônia. 2. ed. Manaus: Valer; Edua, 2003.

BRASIL. Ministério da Educação. Conselho Nacional de Educação. Câmara de Educação Básica. Diretrizes Curriculares Nacionais para a Educação Escolar Quilombola: algumas informações. Brasília, DF: MEC/SEB, 2011.

BRASIL. Ministério da Educação. Conselho Nacional de Educação. Conselho Pleno. Diretrizes Curriculares Nacionais para a Educação das Relações Étnico-Raciais e para o Ensino de História e Cultura Afro-Brasileira e Africana. Brasília, DF: MEC/SEB, 2004.

CAVALCANTE, Ygor Olinto Rocha. Fugindo, ainda que sem motivos: escravidão, liberdade e fugas escravas no Amazonas Imperial, In: SAMPAIO, Patrícia M.(Org.). O fim do silêncio. Presença negra na Amazônia. Belém: Açaí/CNPq, 2011.

. "Uma viva e permanente ameaça": resistência, rebeldia e fugas de escravos no Amazonas Provincial (c.1850- c. 1882). 2013. Dissertação (Mestrado em História Social) Instituto de Ciências Humanas e Letras, Universidade Federal do Amazonas, Manaus, 2013. 
CERQUA, Dom Arcângelo. Clarões de fé no Médio Amazonas. 2. ed. Manaus: ProGraf Gráfica e Editora, 2009.

COSTA, Francisca Deusa Sena da. Quando viver ameaça a ordem urbana. Trabalhadores urbanos em Manaus 1890-1915. 1999. Dissertação (Mestrado em História Social) Programa de Estudos Pós-Graduados em História, Pontifícia Universidade Católica de São Paulo, São Paulo, 1999.

COSTA, Jéssyka Sâmya Ladislau Pereira. Escravos nos anúncios: compra, venda e aluguel de cativos em Manaus (1854-1884). In: ENCONTRO REGIONAL DE HISTÓRIA, 6., 2014 Rio de Janeiro. Anais [...] Rio de Janeiro: ANPUH, 2014.

Escravos negros no mundo do trabalho na Manaus oitocentista (1850-1884). 2016. Dissertação (Mestrado em História) - Departamento de História, Universidade Federal Fluminense, Niterói, 2016.

CHAMBOULEYRON, Rafael. Escravos do Atlântico equatorial: tráfico negreiro para o estado do Maranhão e Pará (séculos XVII e início do XVIII). Revista Brasileira de História, São Paulo, v. 26, n. 52, 2006.

CHAMBOULEYRON, Rafael. O governo dos sertões. Açúcar, aguardente e índios na Amazônia Colonial. Texto apresentado no Seminário de Estudos Coloniais/UFPA, outubro de 2007.

DELGADO, Lucilia de Almeida Neves. História Oral. Memória, tempo, identidade. Belo Horizonte: Autêntica, 2006.

FIGUEIREDO, Arthur Napoleão; VERGOLINO, Henry, Anaíza. Alguns elementos novos para o estudo dos batuques de Belém. In: SIMPÓSIO SOBRE A BIOTA AMAZÔNICA;

Antropologia, 1966, Belém. Atas. Belém: Conselho Nacional de Pesquisa, 1966. v. 2.

GALVÃO, Eduardo. Santos e visagens: um estudo da vila de Itá, Baixo Amazonas. 2. ed. São Paulo; Brasília: Ed. Nacional, 1976.

HALL, Stuart. Da diáspora: identidades e mediações culturais. Tradução Adelaine La Guardiã Resende et. al. Belo Horizonte: Editora UFMG; Brasília: Representação da UNESCO no Brasil, 2003.

LIMA, Marta Goreth Marinho; PEREIRA, Elves Marcelo Barreto. Populações tradicionais e conflitos na Amazônia. Revista Geografias, Belo Horizonte, v. 3, n. 1, p. 107-119, jan./jun. 2007.

LIMA, Henrique Espada. Sob o domínio da precariedade: escravidão e os significados da liberdade do trabalho no século XIX. Topoi, Rio de Janeiro. v. 6, n. 11, p. 289-326, jul./dez. 2005.

MAUÉS, Raimundo Heraldo. Padres, pajés, santos e festas: catolicismo popular e controle eclesiástico. Um estudo antropológico numa área do interior da Amazônia. Belém: Cejup, 1995.

MEIHY, José Carlos Sebe Bom. Manual de História Oral. 4. ed. São Paulo: Edições Loyola 1996.

MELLO, Marcia Eliane Alves de Souza e. Fé e Império: as juntas das missões nas conquistas portuguesas. Manaus: Editora da Universidade Federal do Amazonas, 2009.

NEVES, Soriany Simas. Interrelações entre mídia e cultura popular: as Pastorinhas de Parintins a partir da lógica das micro e macro redes comunicacionais. 2010. Dissertação (Mestrado em Ciências da Comunicação) - Instituto de Ciências Humanas e Letras, Universidade Federal do Amazonas, Manaus, 2010.

Entre o profano e o religioso. Amazonas Faz Ciência, Manaus, n. 16, abr./jun. 2010. Entrevista concedida a Luís Mansuéto. 
NEVES, Auricléa Oliveira. Virgem Maria do Mundo para a Amazônia. Amazonas Faz Ciência, Manaus, n. 16, abr./jun. 2010. Entrevista concedida a Marcelo Vasconcelos e Camila Carvalho.

OLIVEIRA, Luiz Antônio Pinto de. Perfil das condições de vida na Amazônia. Cadernos de Estudos Sociais, Recife, v. 12, n. 2, p. 181-202, jul./dez. 1996.

PINHEIRO, Luís Balkar Sá Peixoto. De mocambeiro a cabano: Notas sobre a presença negra na Amazônia na primeira metade do século XIX. Terra das Águas, Brasília, v. 1, n. 1, p. 148-172, 1999.

PORTELLI, Alessandro. O que faz a história oral diferente. Projeto História, São Paulo, n. 14, p. 25-39, fev. 1997.

POZZA NETO, Provino. Ave Libertas: ações emancipacionistas no Amazonas Imperial. 2011. Dissertação (Mestrado em História Social) - Instituto de Ciências Humanas e Letras, Universidade Federal do Amazonas, Manaus, 2011.

RANCIARO, Maria Magela Mafra de Andrade. Andirá: memória do cotidiano e representações sociais. Manaus: EDUA, 2004.

REIS, Arthur Cezar Ferreira. O negro na empresa colonial portuguesa. In: Tempo e vida na Amazônia. Manaus: Edições Governo do Estado do Amazonas, 1965

ROCHA, João Marinho. Cultura, memória e identidade quilombola: narrativas orais sobre as festas populares da Comunidade de Santa Tereza do Matupiri, Barreirinha-Amazonas. In: CONGRESSO PAN-AMAZÔNICO DE HISTÓRIA ORAL, 2., 2013, Rio Branco. Anais [...]. Rio Branco, Universidade Federal do Acre, 2014.

RODRIGUES, Renan Albuquerque. Vidas despedaçadas. Impactos socioambientais da construção da Usina Hidrelétrica de Balbina (AM), Amazônia Central. 2013. Tese (Doutorado em Sociedade e Cultura na Amazônia) - Instituto de Ciências Humanas e Letras, Universidade Federal do Amazonas, Manaus, 2013.

SAMPAIO, Patrícia Melo. Floresta Negra: A experiência e os impactos da escravidão africana na Região Amazônica. Carta Fundamental, São Paulo, p. 28-31, 19 nov. 2014.

Por uma história da escravidão africana e da presença negra na Amazônia. In: 0 fim do silêncio. Presença negra na Amazônia. Belém: Açaí; CNPq, 2011.

Escravos e escravidão africana na Amazônia. In: O fim do silêncio. Presença negra na Amazônia. Belém: Açaí; CNPq, 2011.

Escravidão e liberdade na Amazônia: notas de pesquisa sobre o mundo do trabalho indígena e africano. In: ENCONTRO DE ESCRAVIDÃO E LIBERDADE NO BRASIL MERIDIONAL, 3., 2007, Florianópolis. Anais [...]. Florianópolis, Universidade Federal de Santa Catarina, 2007. Disponível em: <http://www. labhstc.ufsc.br/pdf2007/53.53.pdf>. Acesso em: 18 jan. 2008.

Os fios de Ariadne: tipologia de fortunas e hierarquias sociais em Manaus: $1840-$ 1880. Manaus: EDUA, 1997.

SILVA, Marilene Corrêa da. O paiz do Amazonas. Manaus: Editora Valer; Governo do Estado Amazonas; Uninorte, 2004.

SILVA, Júlio Cláudio. Memória e identidade nos relatos dos quilombolas da comunidade de Santa Tereza do Matupiri, Barreirinha, Amazonas. In: CONGRESSO PAN-AMAZÔNICO DE HISTÓRIA ORAL, 2., 2013, Rio Branco. Anais [...]. Rio Branco, Universidade Federal do Acre, 2014.

SILVA, Jamily Souza da. A Festa de São Benedito no Bairro da Praça 14. In: O fim do silêncio. Presença negra na Amazônia. Belém: Açaí; CNPq, 2011. 
WAGLEY, Charles. Uma comunidade amazônica: estudo do homem nos trópicos. Tradução de Clotilde da Silva Costa. 3. ed. Belo Horizonte: Itatiaia; São Paulo: Editora da Universidade de São Paulo, 1988.

\section{Fontes orais: pesquisa de campo}

Maria Amélia dos Santos Castro, 56 anos, ex-presidente da Federação Quilombola, Articuladora, moradora da Comunidade do Matupiri. Entrevista realizada em 10 e 12 de setembro de 2016.

Tarciara Raquel dos Santos Castro, 32 anos, professora. Entrevista realizada em 10 e 12 de setembro de 2016.

Recebido em agosto de 2018. Aprovado em dezembro de 2018. 